Portland State University

PDXScholar

\title{
A Renewed Look at Ideology and Legislative Professionalism
}

Jacob Voegele

Portland State University

Follow this and additional works at: https://pdxscholar.library.pdx.edu/honorstheses Let us know how access to this document benefits you.

\section{Recommended Citation}

Voegele, Jacob, "A Renewed Look at Ideology and Legislative Professionalism" (2014). University Honors Theses. Paper 48.

https://doi.org/10.15760/honors.92

This Thesis is brought to you for free and open access. It has been accepted for inclusion in University Honors Theses by an authorized administrator of PDXScholar. Please contact us if we can make this document more accessible: pdxscholar@pdx.edu. 
A Renewed Look at Ideology and Legislative Professionalism

\begin{abstract}
by
Jacob Voegele

An undergraduate honors thesis submitted in partial fulfillment of the requirements for the degree of

Bachelor of Arts

in

University Honors

and

Political Science
\end{abstract}

Thesis Adviser

Richard Clucas

Portland State University 


\section{Table of Contents}

Section One: Legislative Professionalism in Context .............................................................. 3

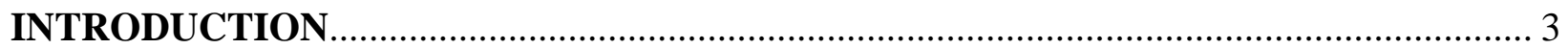

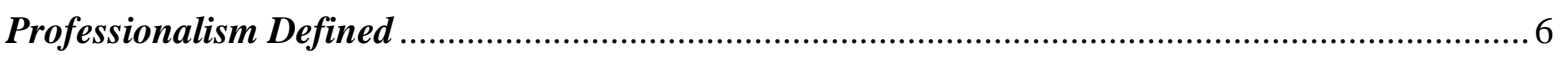

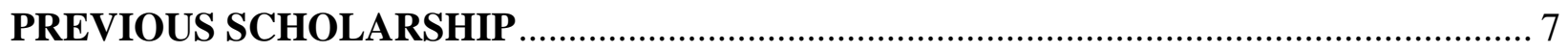

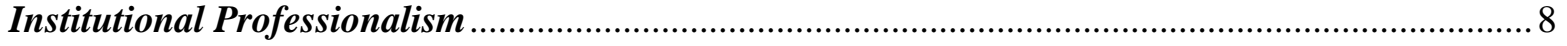

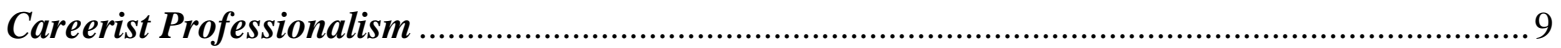

Measuring Legislative Professionalism: The Squire Index ................................................... 11

EXPLANATIONS FOR PROFESSIONLSIM .......................................................... 13

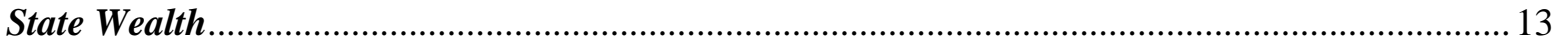

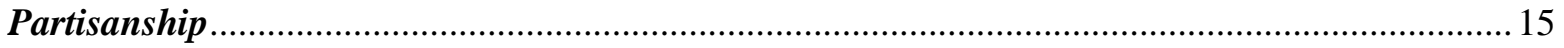

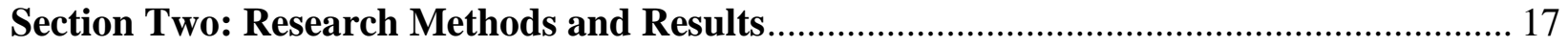

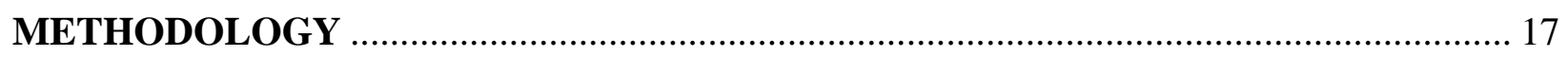

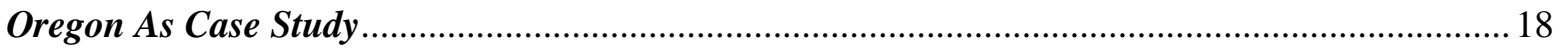

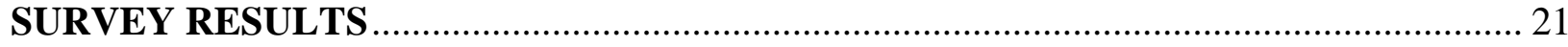

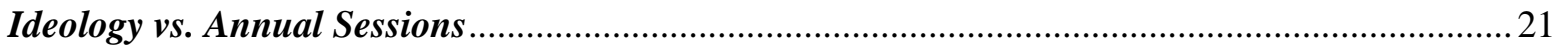

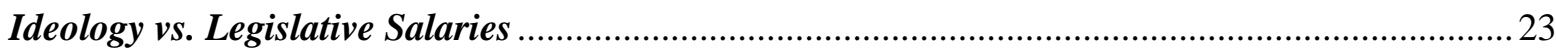

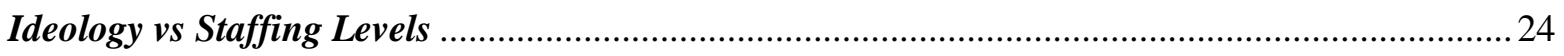

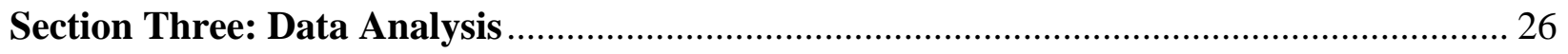

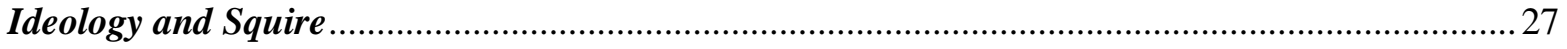

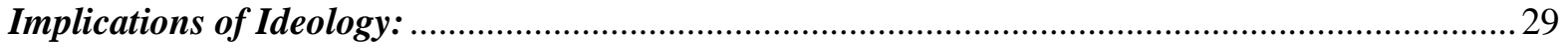

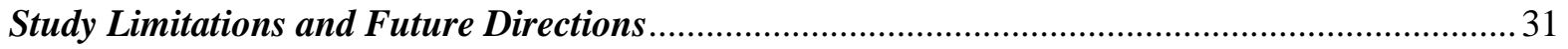

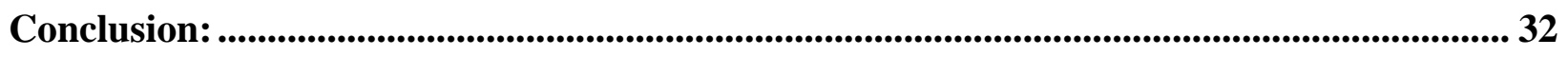

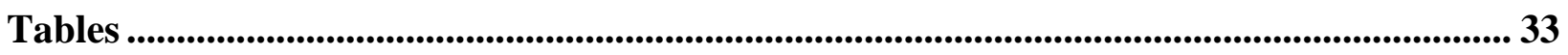

Figures..................................................................................................................................................... 36

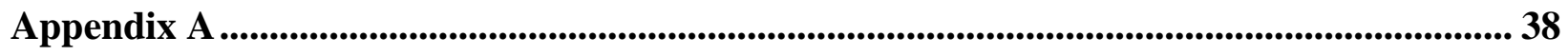

Appendix B ................................................................................................................................................. 40

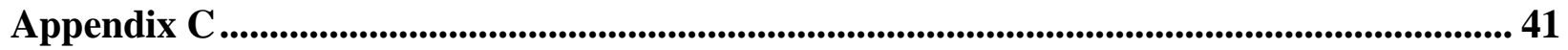

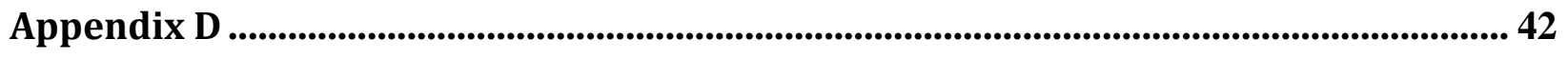

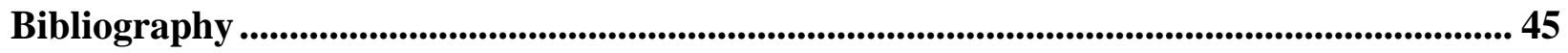




\section{Section One: Legislative Professionalism in Context}

\section{INTRODUCTION:}

To even the most armature observer of American politics one dichotomy will seem very familiar: Democrats believe the government to be a positive force for good while Republicans are adamant in their constant skepticism of the ability of government to accomplish much of anything. "Too much government," "too many regulations," and "too many taxes" are phrases all common in Republican speeches, campaigns, and policy proposals. Ever since New Deal programs of the 1930s mostly Keynesian Democrats have transformed the role of the federal government, involving it in almost every sector of economic life in American. This transition left an impact on state and local governments as well. Increasing demands on states came as Congress funneled money into their legislatures through grants, stimulus projects and new federally mandated programs. States legislatures, lacking the same institutions and resources as congress, struggled to keep up with the new demands put on them. By the end of the 1950s, Legislatures continued to look amateurish in comparison to Congress - legislators on the state level were understaffed, underpaid, and were only in session a few months per year.

Political scientist Alexander Heard described the legislature of the mid-twentieth century as institutionally "poorly organized; technically ill-equipped; functioning with inadequate time, staff, and space; and operating with outmoded procedures and committee systems" "1 Additionally legislators were poorly compensated for their time spent in the legislatures, and consequently approximately $97 \%$ of legislators considered themselves something other than a "full-time

\footnotetext{
${ }^{1}$ Alan Rosenthal, Engines of Democracy: Politics \& Policymaking in State Legislatures, (Washington, DC: CQ Press, 2009), 183-184
} 
legislator."2 This all changed starting in the mid-1960s as legislatures began to fashion themselves in a manner similar to Congress.

The purpose of this paper is to examine the extent to which ideology and partisanship can be utilized to explain legislative professionalism. Most scholars remain focused on economic factors that influence professionalization. While these factors remain important, it is my assertion that ideological influences cannot be completely dismissed and need to be examined further. To demonstrate this point, I will first provide an over of the professionalization movement as well as cover some of the major scholarship that has been produced on this topic over the past forty years. Following that I will explicate the results of survey research I conducted of Oregon legislators. Lastly the survey findings are compared with previous scholarship to see the extent to which they comport with previous conducted research in this area. This study concludes that under some circumstances legislator ideology can have an impact over a State's propensity to professionalize, however, that effect is often limited by the comparative wealth (GDP), of each state.

\section{LEGISLATIVE PROFESSIONALISM}

In 1960s, the Citizens Conference of State Legislatures (CCSL), published a book entitled The Sometime Governments, in which state legislatures were evaluated for how "functional, accountable, informed, independent and representative" ${ }^{3}$ they were and ranked accordingly from one to fifty. The rankings served as a "wakeup call" for many state lawmakers, as "no state wanted to remain ranked in the bottom half of the list or below its neighbors or rivals." ${ }^{4}$ Due in part to the CCSL, the mid-1960s through the 1980s saw a reform movement

\footnotetext{
2 " Legislators' Occupations in all States, 1976, 1986, 1993, 1995, 2007 (percentages)," NCLS website. http://www.ncsl.org/legislatureselections/legisdata/legislator-occupations-national-data.aspx (fix)

${ }^{3}$ Outlined in more detail in Appendix A

4 "The Sometime Governments Revisited," NCLS website. http://ncsl.typepad.com/the_thicket/2010/07/the-sometime-governmentsrevisited.html
} 
"sweep through the nation, with state after state moving to professionalize its legislature." 5

Within the short span of a few decades, legislatures rebuilt themselves. Following

recommendations from the CCSL report, several state legislatures passed reforms to increase time they spent on their tasks, establish or increase their professional staffs, streamlined their procedures, enlarge their facilities, invigorated their processes, (attend) to their ethics, disclose their finances, and reduce their conflicts of interests."

The original report on legislative professionalism published by the CCSL created their own criteria of what a professional legislature should look like, and measured each state's legislature against that standard. These criteria, as previously outlined, were as follows: that a legislature ought to be "Functional, Accountable, Informed, Independent, and Representative." However, a set of recommendations also accompanied the criteria (Appendix A). To a modern reader familiar with Congress, these recommendations may seem commonplace. For example "adequate office facilities" for legislatures is something every citizen would expect their legislators to have access to. This was not in the case in most state legislators of the 1960s. Former Oregon Governor Ted Kulongoski remembers serving in the Oregon legislature in the early 1970's and how few resources were available to the legislature in those days. "When I first started in the legislature, (legislators) didn't have (their) own offices," Kulongoski recalls, "the capitol expansion in the late 1970's finally changed that." 7 The Governor's statement refers to the 12.5 million dollar renovation in 1977 which "added further space for legislative offices, hearing rooms, support services, a first floor galleria, and underground parking." ${ }^{8}$ Renovations

\footnotetext{
${ }^{5}$ Richard Clucas, "The Legislature," Oregon Politics and Government: Progressives versus Conservative Populists, ed. Richard A. Clucas, et al. (Omaha: University of Nebraska Press, 2005), 120

${ }^{6}$ Alan Rosenthal, "The Legislative Institution: Transformed and at Risk," The State of the States, ed. Carl E. Van Horn, (Washington, DC: CQ Press, 1981) 69. It should be noted that reform movements in several states also took place in the decades previous to the issuing of the CCSL report. See (Squire, 2009).

${ }^{7}$ Kolongoski, Ted. Lecture. Feb 15, 2013.

${ }^{8}$ Oregon Legislature Website. http://www.leg.state.or.us/capinfo/legislative_history.pdf
} 
were necessary as the original building, constructed in 1938, merely consisted of the main two legislative chambers with very limited office space. Over time, changes to state legislatures such as the one outlined by Gov. Koulongoski became known among scholars as "legislative professionalization."

While the CCSL had set out general recommendations on state legislatures could improve their functions, a concise definition of Professionalism had not yet been agreed upon. Imagine a hypothetical scenario were a researcher were attempting to compare Texas with California. What if Texas increased their legislative session to 8 months a year but provided no staffing to members, while California only held 4 month sessions but provided resources for each of their legislators to hire 2 staff members. Both states had adopted some of the CCSL reforms. Fictional California became more "functional" than Texas in regard to staffing yet less "functional" with shorter session lengths. In this hypothetical scenario which legislature is to be considered more "professionalized"? Scholars agreed that the best way to solve this problem was to use Congress as the standard of a professionalized legislature with which compare the relative level of professionalization of each state legislature. A standard definition of professionalism emerged.

\section{Professionalism Defined}

The commonly accepted general definition of "professionalism" is the movement of state legislatures toward the same level of organizational support as Congress. This means "providing (state legislatures) with adequate resources to do their jobs in a manner comparable to (Congress)." Adequate resources include, but are not limited to, "(expanded) legislative sessions, superior staff resources, and sufficient pay to allow members to peruse legislative

\footnotetext{
${ }^{9}$ Neal D. Woods and Michael Baranowski, "Legislative Professionalism and Influence on State Agencies: The Effects of Resources and Careerism,” Legislative Studies Quarterly, 31(2006), 589.
} 
service as their vocation" ${ }^{10}$ All of these variables are tracked by the National Conference of State Legislators (NCSL). The composite of these factors has lead the NCSL to group modern state legislatures into three categories. Professional, semi-professional, and amateur, (sometimes also called "Citizen-Based"). A professional legislature as defined previously, is a body that closely resembles congress in that it meets full time, has full-time, proficient staff, and compensates its members and staff in a manner commiserate with their work load and education. ${ }^{11}$ Semiprofessional legislatures are ones in which meet some, but not all, of the qualifications being professional legislature. Perhaps they do have some full time staff but a legislature that only meets part time, or they meet annually but the legislators are not compensated as adequately as a professional legislature would be. Finally, amateur legislatures are ones in which legislatures are barely compensated for their time, staffing is limited and rarely exists past the session, and sessions only last a few months a year, or in some states every other year. Most states have professionalized to some degree and fall into the middle category of semi-professional. These NCSL definitions are just a more descriptive way articulate how similar a or dissimilar a given state legislature is when compared to congress. While no state is close to the organizational level of Congress, ${ }^{12}$ these terms are quick descriptive categories scholars can used to compare one state to another.

\section{PREVIOUS SCHOLARSHIP}

One of the first scholars to track the reformation of state legislatures was Alan Rosenthal, considered by many academics to be the man "who reshaped legislatures." ${ }^{13}$ Rosenthal was one of the first scholars to give major academic attention to the professionalization movement in state

\footnotetext{
${ }^{10}$ Peverill Squire, "Measuring State Legislative Professionalism: The Squire Index Revisited," State Politics and Policy Quarterly, 7(2007): 211

${ }^{11}$ CCSL report, (Figure 1)

${ }^{12}$ The Squire Index, to be discussed later, demonstrates California, the most professional state legislature, to only be $2 / 3$ rds as professional as Congress.

${ }^{13}$ http://www.nytimes.com/2013/07/12/nyregion/alan-rosenthal-who-reshaped-legislatures-dies-at-81.html?_r=0 (November 15, 2013.)
} 
legislatures. Distinctive about Rosenthal was the ability of his work to influence state legislatures and instigate substantive change in the way they function. His article, "An Analysis of Institutional Effects: Staff Legislative Parties in Wisconsin," 14 was one of eight case studies he published ${ }^{15}$ examining legislative functions in various states. Rosenthal's findings ${ }^{1617}$ were widely read, in particular by the state legislatures about which the articles were written. This in turn inspired other state legislatures to initiate their own reforms. ${ }^{18}$ The real world effect of his work on state legislatures is considered by many to be Rosenthal's greatest contribution: "His ability to bridge the gap between scholarship and politics (...) helped to modernize and strengthen state legislatures, encouraging them to become equal partners in our three-part government," writes Karl Kurtz, a scholar of state legislative politics. Rosenthal was not merely content to research and publish scholarship about legislative professionalization - he took an active role in encouraging states to reform. Being one of the "founding fathers" of the study of legislative professionalism, Rosenthal remains immensely important; however, Rosenthal was adamant that legislative professionalism only ought to focus on the legislature itself, and not the members which comprise it. Therefore, Rosenthal kept his research focus mainly on what he called "institutional professionalism."

\section{Institutional Professionalism}

Institutional professionalism refers to "the improvement of legislative facilities, the increase in information available to the legislature, the size and variety of legislative staffs, the time spent at legislative work, etc." 19 These aspects are "institutional" in the sense that they have

\footnotetext{
14 Journal of Politics, 32 (August 1970), pp. 531-562

${ }^{15}$ As author and/or editor

${ }^{16}$ Rosenthal, Alan. "Turnover in State Legislatures," American Journal of Political Science, 27

(August 1974), pp. 609-616

${ }_{17}$ The State of State Legislatures: An Overview," Hofstra Law Review, 4 (Summer 1983), pp 1185-1204

$18 \mathrm{http} / / /$ www.ncsl.org/research/about-state-legislatures/alan-rosenthal-wizard-of-democracy.aspx

(November 15, 2013.)

${ }^{19}$ Woods, 589.
} 
only indirect influence on individual legislators and have more to do with the function of the legislature as a whole. The increases in length of sessions, for example, allowed the legislature more time to adequately consider and craft legislation on larger and more complex issues. Expanded facilities for office space not only provided members with a workplace but gave them the opportunity to hire additional staff. Increased levels of non-partisan staff, lawyers to help draft legislation, economists and accountants to help forecast revenues and expenditures, and also committee staff, assist the legislature by providing internal sources of information as well as streamlining the legislative process. The advent of partisan staff also helped to support the legislature. As with all non-partisan staff, they work to keep their legislator informed and can bring expert knowledge the legislators may not otherwise have access to. With the demands of policy making, legislators do not have sufficient time to answer the hundreds of emails and phone calls they get on a weekly basis. While some of this work can be mundane, partisan staff play a valuable role in creating awareness around what issues are of concern to constituents as well as forging a relationship between the legislator and his/her constituents. Even in amateur or semi-professional legislatures legislators have realized that having a limited number full time staff in the office year round helps to compensate for members only being there part time. ${ }^{20}$ In addition to Institutional aspects of professionalism, Rosenthal also identified characteristics that could be categorized as Careerist Professionalism, or "Careerism."

\section{Careerist Professionalism}

Careerism is the extent to which members consider being a legislator as their full time vocation. ${ }^{21}$ The division between Careerism and Institutional Professionalism is an important one to make. While some states have professionalized their legislatures institutionally, with expanded

\footnotetext{
${ }^{20}$ Hedge (1998), 115

${ }^{21}$ Ibid
} 
facilities, sessions, and staff, the not all legislators serving in them do not consider themselves to be professional legislators, with careers outside of the legislature.

Professors Karl Kurtz, Rick Farmer, Thomas Riddle, and David Hedge are notable for their interest in careerism of state legislators. Recent statistical data has shown a marked increase in the number of legislators who consider their job in the legislature to be their full time vocation. Karl Kurtz has authored a large amount of scholarship explaining this trend, including a recent article examining legislator's perceptions of how much time they spend "on the job."22 Kurtz has also been active in what has been the most contentious debates concerning careerism, and that is the "case of term limits." Farmer and Riddle wrote a book, ${ }^{23}$ edited by Kurtz, which explores the negative effects term limits have on institutional memory and consensus building within the legislature. ${ }^{24}$ Thad Kousser of UC San Diego also authored a book demonstrated term limit to have a detrimental effect on the ability of legislators to build the relationships necessary to effective work together. In fact, the majority of scholarship concerning careerism seems agree that term limits do little to accomplish their stated goal: to curb the average length of time legislator spend in office and prevent careerism. Kousser and Kurtz prove that regardless of term limits legislators on the state level rarely spend more than a few terms in a given office. Those who think of themselves as career legislators use the legislature as a stepping stone to higher office. $^{25}$ The only supportive literature that can be found for term limits come in the form of opinion pieces in newspapers and magazines. Some of these articles are well written but they

\footnotetext{
${ }^{22}$ Kurtz, Karl. T, Gary Moncrief, Richard G. Niemi, and Lynda W. Power. 2006. "Full-Time, Part-Time, and Real Time: Explaining State Legislators' Perceptions of Time on the Job." State Politics and Policy Quarterly 6:322-38.

${ }^{23}$ Farmer, Rick; Riddle, Thomas. "Legislative Leadership" Institutional Change in $\quad$ American Politics: The Case of Term Limits, edited by Karl T. Kurtz, Bruce Cain, and Richard G. Niemi, 55-72. Ann Arbor: University of Michigan Press, 2007.

${ }^{24}$ Institutional Change in American Politics: The Case of Term Limits, edited by Karl T. Kurtz, Bruce Cain, and Richard G. Niemi, 55-72. Ann Arbor: University of Michigan Press, 2007.

${ }^{25}$ Kousser, Thad. Term Limits and the Dismantling of State Legislative Professionalism (Cambridge University Press, 2005),
} 
have no basis in scholarship and run counter to the substantive amount of research that has been produced on the subject. While careerism has been a much more popular topic of discussion over the last several decades, most scholars remain interested in the institutional changes wrought by professionalization.

The general view of scholars is that the general move to greater professionalization within state legislatures is a good thing. With the scope of authority that states have acquired and the complexity of issues they deal with, it is important that the institutional structure of their legislatures be organized in manner more akin to Congress. All states have moved in this direction to some degree. To track the relative changes within each state scholars began to create formulas with which could measure legislative professionalism. While the NCSL blue-white-red representation of professionalism makes for a nice presentation, a quantifiably measurement is much more useful in comparing states. These formulas, for the most part, utilized congress as the standard by which all states could be compared. The measurement most commonly referenced by scholars today is the "Squire Index."

\section{Measuring Legislative Professionalism: The Squire Index}

Peverill Squire, currently a professor of political science at the University of Missouri, is best known for the creation of the "Squire Index," which measures the extent to which state legislatures are "professional" compared to Congress. The Squire Index, created by Peverill Squire, utilize three variables to measure professionalization: length of legislative session, staff

resources, and member pay. ${ }^{26}$ The states are ranked on a scale of zero to one, with one indicating that a state complete resembles Congress and zero indicating no resemblance whatsoever. A brief sampling of five states will make the rankings clear.

\footnotetext{
${ }^{26}$ Peverill Squire, "Measuring State Legislative Professionalism: The Squire Index Revisited,” State Politics and Policy Quarterly, 7(2007): 211
} 
[Insert Table 1 here]

California, the highest ranked state in Squire's Index, pays its legislators nearly as much as members of Congress with annual salaries of $\$ 116,000 .{ }^{27}$ California's legislature meets annually with no limit on session length, and has an average of 8.9 staff per member. By contrast, New Hampshire pays its members a token $\$ 100$ annually and only meets forty-five days a year. In between these two extremes are states such as Texas and Oregon. Both these states pay their legislators a modest $\$ 16,000$ and $\$ 25,000^{28}$ respectively, and as of 2003 were only meeting on a biennial basis. Legislators in these states were provided office space and resources to high temporary staffs while in session. In slight disagreement with Rosenthal, Squire posits that both "Institutional" and "Careerist" Professionalism play a role in professionalization and therefore both are included calculating a state's score on in his Index. However Squire is clear in distinguishing the relationship between Institutional Professionalism and Careerist Professionalism - while some states have professionalized their legislatures institutionally with expanded sessions and staff, the legislators serving in them do not consider themselves to be professional legislators, with careers outside of the legislature. ${ }^{29}$ Therefore according to Squire, "a professional legislature need not necessarily be a career legislature," 30 meaning that a legislature could be fully professionalized in its institutions but still have legislators that serve part time. Despite this fact, data regarding legislature vocation, as discussed earlier, has shown a marked increase in the number of legislators who consider their job in the legislature to be their full time vocation. Some legislatures continue to professionalize while others lag behind. Several

\footnotetext{
${ }^{27}$ Ibid, 87

${ }^{28} \mathrm{Ibid}, 87$, figures accurate as of 2007

${ }^{29}$ Squire, "Measuring State Legislative Professionalism," 215

${ }^{30}$ Squire, "Measuring State Legislative Professionalism," 215
} 
studies have examined trends which might explain this disparity, yet most have greatly undervalued ideology as a possible explanation.

\section{EXPLANATIONS FOR PROFESSIONLSIM}

Much of the pervious scholarship interested in professionalism has focused on state wealth as a leading indicator contributing to whether a state will be more or less professionalized. ${ }^{31}$ A modest amount of other scholarship has looked at ideology and party affiliation, state political culture, ${ }^{32}$ and state population. The later of these, state population, has been demonstrated to be nearly identical to state wealth, and is considered by most scholars to be synonymous with state wealth with respect to professionalism. ${ }^{33}$ Without a doubt the established scholarship has demonstrated the state wealth theory, (comparative GDP levels), as a solid explanatory framework - states with larger economies will have larger revenue bases (tax income), and therefore additional resources for legislative pay and staff. When considered by itself, the state wealth theory fails to account for several outliers. Many states with similar sized economies receive vastly different professionalization scores on the Squire Index. Might ideological factors better explain these differences? State wealth still functions as an adequate explanation for professionalism, it is the contention of this paper that certain cases $\mathrm{m}$ can be better understood when considering ideological factors.

\section{State Wealth}

Since the majority of monetary resources of a State are derived from tax revenue, a state with a larger GDP will likely have a larger flow of revenue with which to work.. Of the states

\footnotetext{
${ }^{31}$ Hamm, Keith; Squire, Peverill. 101 Chambers: Concress, State Legislatures, and the Future of Legislative Studies. Ohio State Unversity Press, Columbus Ohio. 2005. p 79

${ }^{32}$ Based largely on Elazar's (1984) typology. For more see, 101 legislatures p 87-88

33 Ibid
} 
with the ten largest economies, seven of them are considered "fully professional," with an average legislator salary of $\$ 52,000 /$ year. ${ }^{34}$ In contrast, the states with the ten smallest economies have an average legislator pay of $\$ 11,000 /$ year. ${ }^{35}$ Beyond increased resources from which to work, this trend is that a larger economy means a more diverse and complex economy. This explains why California, which boasts a GDP of nearly two trillion dollars, pays their legislators approximately $\$ 110,000 / y e a r .{ }^{36}$ Such a salary may seem outrageously high to a legislator serving in the Rhode Island legislature making a meager $\$ 14,000 /$ year. ${ }^{37}$ However, it is logical that legislators in states with larger economies and populations have more policy decisions to make, more constituents issues to deal with, and a greater diversity of interests to balance; therefore, they receive a larger salary and have instituted more professional mechanisms to deal with the workload.

[Figure 1 about here]

Figure 1 compares the 2003 GDP of each State with the given Squire Index rank for the same year. ${ }^{38}$ A plausible trend line emerges demonstrating a positive connection between state wealth and professionalism. However this relationship is not perfect as several clear outliers emerge. Texas had a 2003 GDP slightly higher than New York yet compensated its legislators at almost one-tenth the rate and additionally only holds sessions biennially; for these reasons Texas received a much lower score on the Squire Index despite its high GDP. Wisconsin and Massachusetts have considerably lower GDP than New York yet scores nearly as high on the Squire Index. At the same time the state of Hawaii has an only slightly higher Squire Index score than Texas however it has a GDP approximately 5 percent that of Texas. Meanwhile Utah, with a

\footnotetext{
${ }^{34}$ Squire, State Legislatures Today: Politics Under the Domes. Ed. Gary Moncreif. Pearson Education, Inc. (2010): p 87.

35 Ibid

36 Ibid

${ }^{37}$ Ibid

${ }^{38}$ California is not pictured in figures one, four and five due to its exceptionally high GDP. California's GDP and Squire Index score was included when calculating the trend line.
} 
GDP only slightly higher than Hawaii, received one of the lowest Squire Index scores given. Despite the fact that many scholars accept the GDP of states as one of the largest indicators, it alone cannot adequately explain the discrepancy between states. Partisanship has emerged as a potential explanation for this discrepancy.

\section{Partisanship}

The explanation from partisanship is based on the assumption that Democrats are, in general, more supportive of an expansion of the role of Government, whereas Republicans generally opposed these policies. The New Deal and Great Society programs are examples from the $20^{\text {th }}$ Century of massive redefinitions of the role of Government in relation to the economy and society. These reforms have largely been supported by Democrats. Some have asserted that because of this general difference between the two parties that states controlled by Democrats would be more likely to become professionalized due to the Democrats propensity to tax at higher levels and spend more money than their Republican counterparts. Yet are democrats more inclined to spend more than their republican counterparts? Neil Malhotra has examined relationship between spending levels, tax rates and professionalization. ${ }^{39}$ Neil Malhotra's research refutes, to some extent, assertions of partisans as an explanation for why some legislatures have professionalized to a greater extent than others. Malhotra (2008) concluded that "professional legislators spend no more than their counterparts in unprofessional bodies," and moreover "these conjectures have been based on either speculation or inattention to the fact that professionalism, as a strategic choice, may be a response to and not a cause of growth in the public sector." ${ }^{40}$ In other words supporters of this theory have it backwards. Malhotra ruled that

\footnotetext{
${ }^{39}$ Neil Malhotra, "Disentangling the Relationship between Legislative Professionalism and Government Spending," Legislative Studies Quarterly 33(2008): 289

${ }^{40}$ Malhotra (2008), 308
} 
the increasing role of Government, through the creation of New Deal and Great Society programs, is one factor that caused of the movement toward professionalism rather than resulting from it. Yet is the argument from partisanship totally without evidence? Morris Fiorina published a preliminary paper arguing there was evidence correlating partisanship with professionalism. ${ }^{41}$

Fiorina argues that a professional legislature favors Democratic over Republican politicians in two ways. First, being a legislator as a full-time occupation is more attractive to a Democrat than to a Republican, and second, policy positions of Democrats tend to favor professionalization more so that Republican policy positions. To provide evidence for these assertions Fiorina looks at two well researched aspects of professionalization: the comparative length of the legislative session in each state and the comparative salaries of legislators. In the state of Ohio, Fiorina notes, the Republicans held the majority of seats in the House every year ${ }^{42}$ from 1946 until 1972 when a thirteen point increase on the Democratic side gave them the majority. What explained this sudden shift in fortunes for the Democrats? Fiorina highlights the 1967 change in the Ohio state constitution to allow annual sessions. With this move, Ohio voters effectively doubled the number of days the legislature would meet in a two year period "from 315 days in the 1967 biennial session, (...) to 717 days in the 1971-72 annual sessions."43

Fiorina admits an individual cases can be anecdotal as concrete evidence of a trend. When data from 31 states is aggregated from 1946-1990, the number of days in session is found to have only marginal influence on Democratic success over time. However, Fiorina's calculations did indicate a statistically minor relationship between legislative salaries and Democratic success. For every $\$ 10,000$ increase in real biennial compensation the Democrats

\footnotetext{
${ }^{41}$ Fiorina, Morris P. "Divide Government in the American States: A Byproduct of Legislative Professionalism?" American Political Science Review. (2004) 88.2: 304-16

${ }^{42}$ Except 1958

${ }^{43}$ Fiorina (1994) 309
} 
saw a very modest .7 percent increase in their seat share across the thirty-one state sample. However, it would be ridiculous to expect that a change in legislative session length or compensation would have an exponential net benefit for democrats. A re-examination of the Squire Index data with consideration given to the political composition of each state legislature will shed further light on the influence of partisanship on professionalism.

\section{Section Two: Research Methods and Results}

\section{METHODOLOGY}

In order to establish a link between political ideology and professionalization, a survey of Oregon state legislature was conducted. The data presented in this paper sheds light onto the perceptions of legislators as to what they think of Professionalism as it pertains to their ideological views and party affiliation. Secondary outcomes will explore how legislators view session length and allocation of resources toward their own salaries, office staff, and legislative resources. This will establish a potential relationship between party affiliation and/or ideology and the tendency to move toward a more a professionalized legislature.

Some social scientists deride case studies as the weakest form of inquiry, particularly when the scope is limited to a single or a few cases. These critics argue that with such a small data set, it is impossible to extrapolate any larger theory from such a limited sample. However, that critique is only valid where cases lack fairly uniform background conditions. In the study of state legislatures, a substantial number of similarities exist between states such that comparison is possible. In this regard Oregon is relevant not only because the history of the professionalization of Oregon's legislature is common to that of other states, but also because it has such a diverse economy and political landscape. Moreover, the work of Robert Yin has 
demonstrated the case study to be extremely useful as a method of testing theoretical frameworks.

\section{Oregon As Case Study}

The modern Oregon economy has strong agricultural and natural resource extraction base in the rural areas as well as a vibrant technology and industry sector in the metropolitan hub of Portland. The types of issues debated in the Oregon Legislature are therefore quire diverse, and therefore common with mostly rural agricultural states such as those in the Midwest as well as states that are densely populated with large industrial economies. The diversity of relevant issues in Oregon creates an environment where the ideological trends can be assumed to reflect the larger trends influencing politics all over America today. ${ }^{44}$ Urban residents are distinctly more liberal/progressive than their conservative rural counterparts. The legislators produced by such an environment would be dissimilar enough in their backgrounds and ideologies that any survey research conducted could be representative of state legislatures all across the United States. From the standpoint of the Squire Index Oregon is also ideally suited for case study research. As of 2003 Oregon was ranked $25^{\text {th }}$ on the Squire Index in terms of its professionalization score. Thus being what the NCSL would call a "semi-professional" legislature, it remains neither overly similar nor overly dissimilar when compared to Congress.

The history of the professionalization of Oregon's legislature is similar to that of many other states. Oregon's most major effort to modernize its legislature was in 1967, a time when dozens of other states were also looking at reform. During that time the legislature "created an advisory committee to study and recommend reforms" and in 1968, the committee's report was

\footnotetext{
${ }^{44}$ Clucas, (2005)
} 
issued and the state legislature chose to adopt some, but not all of the recommended reforms. ${ }^{45} 46$ Similar to other states, ${ }^{47}$ initial reforms included "increased legislators' pay, removed constitutional restrictions on session lengths, and hired more staff." ${ }^{48}$ As with many other states, the expanded session length and additional staff was meant to increase institutional professionalism by giving legislators the professional support they needed to do their jobs. The increase in salary worked to make the position of "legislator" somewhat more financially viable as permanent vocation. ${ }^{49}$ Despite these early reforms, legislators were still left without offices or full-time staff. To create this space renovations were necessary as the original building, constructed in 1938, merely consisted of the main two legislative chambers with very limited office space. The additional space made a huge difference as it gave each member a physical location within the building to house their staff, hold meetings, and work. It was not until the 1980 's that the legislature voted to allocate funds for limited staffing year round. This had the effect of better preserving institutional memory as staff no longer severed on a temporary basis. ${ }^{50}$ More recent changes include the creation of annual sessions starting in 2012, allowing Oregon to join the all but four states who hold annual sessions. ${ }^{51}$ With the legislature holding a shortened one-month session in even numbered years in addition to the 6-month session held in odd numbered years. Additionally in 2011 the democratically controlled legislature approved modest increases in legislator and staff salaries. These recent reforms were not without controversy and debate. The survey research in this publication will help to explain ideological influences on these changes.

\footnotetext{
${ }^{45}$ Clucas (2005), 120

${ }^{46}$ See Appendix A for recommended reforms.

${ }^{47}$ As of 1998 , over $4 / 5^{\text {th }}$ of state legislators had adopted such basic reforms. See Hedge (1998), 5

${ }^{48}$ Clucas (2005), 120

${ }^{49} \mathrm{Ibid}$

${ }^{50}$ Thad Kousser, Term Limits and the Dismantling of State Legislative Professionalism, (New York: Cambridge University Press, 2005), 53-57

${ }^{51}$ Hedge (1998), 116
} 
One final general justification for the use of case study research is grounded in the work of Robert Yin (1981). Yin defines case studies as a "research strategy" which is "to be likened to an experiment, a history, or simulation." ${ }^{, 52}$ He goes on to rightly assert that as a mode of experiment, case studies are utilized to test existing theories that explain a phenomenon or asses the validity of new explanations for that phenomenon. In relation to my own inquiry, the relationship between party affiliation and ideology as it relates to legislative professionalism is what my case study tests. The only way to test such a theory was to look at a state where reforms involving aspects of professionalization were occurring, and ask legislators what they thought about those reforms. Ideology or party affiliation can be said to have an influence on such outcomes if the majority of one particular party of ideological position favor certain reforms over others. Survey data is useful in this regard as it can identify if factors such as ideology play a role in why a particular legislator might favor professionalism. The outcome of such research will shed light on the issue of ideology and its relationship with professionalism.

\section{Survey Construction, Distribution, and Return Rate}

It was my hypothesis that when ideological factors are compared with responses from issues such as session length or legislator salaries a trend would emerge. In constructing the survey, I first asked legislators to identify their political party and ideological affiliation, as well as whether their district was "urban," "rural," or a "mixture" of the two. Questions were then formulated to ascertain legislator perceptions regarding the switch to annual sessions, current legislator salary and staffing levels. The answers to these questions would be compared with the partisan identification of the participant. (For a complete view of the survey, see Appendix D).

\footnotetext{
${ }^{52}$ Yin, Robert. Administrative Science Quarterly, Vol. 26, No. 1 (Mar.,1981), pp. 59
} 
Surveys were physically distributed with a pre-addressed envelope to member offices at the state capitol building in Salem. Included with the survey was a one page informational ${ }^{53}$ that $^{2}$ informed the members of the purpose of the survey as well as the assurance that their responses would be anonymous. An attempt was made to distribute over ninety surveys, one to every legislator; however, three offices declined to participate in the survey and I could not distribute two due to a lack of staff present in the office. In the following weeks, I received twenty-nine responses to the survey leaving a return rate of 34 percent. Of the responses received, nineteen were from Democratic legislators while only ten were from Republicans. Considering the Democrats currently hold majorities in both houses this is not totally unexpected. This leaves a partisan participation at a rate of twenty out of fifty, (40 percent), for democrats and nine out of forty, (22.5 percent), for Republicans. Republicans were represented at a slightly lower percentage than democrats, however such return rates are not outside of the norm for survey research and adequate for the purposes of my analysis.

\section{SURVEY RESULTS}

\section{$\underline{\text { Ideologv vs. Annual Sessions }}$}

As already mentioned, nineteen out of the twenty-nine survey participants identified as Democrats while ten identified as Republicans. Table two represents the survey data gathered from survey questions two and three and illustrates the partisan breakdown of legislature. The Democratic delegation was almost evenly split between identifying as liberal and moderate. Two Democrats chose not to identify their ideology. Conversely only one Republican identified themselves as moderate, while eight picked conservative. Democrats are ideologically center-left and represent mostly urban areas while Republicans are solidly on the right with constituents that

\footnotetext{
${ }^{53}$ See Appendix C
} 
live in mostly rural areas. These results comport with trends nationally, as cities all over the country tend to be more ideologically liberal and strongly associated with the Democratic Party. Having collected data from a solid representation of ideological positions, those positions can now be compared with the rest of the survey data.

[Table Two about here]

Table three contrasts party affiliation, political ideology, and district composition with the question of Oregon's 2011 shift to annual sessions. Party affiliation revealed a split among Republicans with a slight majority being against annual sessions. Ninety percent of Democrats, on the other hand, are largely in favor of switching to annual sessions. Of the 18 Democrats who approve of the change, three take the position that the sessions should be expanded even further. Party ideology sheds even more light on the question. Some Conservatives (37\%), a majority of Moderates (85.7\%) and Liberals (75\%), feel the change to annual sessions was necessary. Those disapproving of the annual sessions are largely (83.3\%) ideologically conservative while all three of those in favor of expanding the session length even further are liberal. In looking a district composition the only clear trend is that those in rural districts are largely opposed to annual sessions. Members who represent urban districts largely feel the switch to annual sessions was necessary with only a few outliers on each side feeling the change was "unnecessary" (one person,) and "didn’t go far enough" (two people). Mixed districts are also largely supportive of the change. It can be concluded, based on this data, that conservative members in rural districts are the mostly likely to be opposed to the expanded session length while liberals and moderates in urban regions are most likely to be supportive. Considering the survey data gathered, one would predict that the vote over the 2011 expansion of session length would fall upon party lines. The voting record, (see figure two), from the 2010 special session of the Oregon 
Legislature on SJR 41, which referred the decision over expanding the legislative session to Oregonians, completely corroborates the findings of the survey, (shown in figure three).

[Table Three about here]

[Figures two and three about here]

When comparing the results of the survey data to the 2010 vote to switch to annual sessions in Oregon, we find near identical numbers. While it is not surprising that the survey data would align with the voting record, the fact that that both closely aligned with each other helps to provide validity to the survey data. The Oregon Senate saw a 24-6-0 vote in favor of annual sessions while the House approved the measure 34-24-2. ${ }^{54}$ The house vote fell almost strictly on party lines with only one member on each side voting against their own party. The Senate had no Democratic "nay" votes, while seven Republicans joined the Democrats in the affirmative. Combining the two chamber votes the measure received an overall 58-30-2 vote. The survey data paints a very similar picture to that of the voting record, with near unanimous support from Democrats while the Republicans were largely split on the issue. It also gives evidence that the split in the Republican party on the SJR 41 can be explained though looking both at ideologically preference as well as district composition. Again, conservative, rural republicans are less likely to support such a change while more moderate Republicans from mixed districts supportive. This trend continues when looking at legislator salaries.

\section{Ideology vs. Legislative Salaries}

Survey data suggests that the issue of legislative salary can still be linked to ideological preferences. After annual sessions became a reality in Oregon, legislators voted for modest increases in salaries as well as an increase in Legislator salary is often a tough issue for

54 “Senate Joint Resolution 41" <http://gov.oregonlive.com/bill/2010/SJR41/> Accessed March 14, 2014 
legislators as it carries with it a lot of political baggage - politicians who vote to raise their own salaries run the risk of negative reactions come election time. This survey seemed to be the ideal time to gain insight into legislator viewpoints being influenced by considerations of reelection campaigns. The survey question given asked legislators to first think about the amount time they commit to their responsibilities as a legislator and then decide if their monetary compensation was commiserate with their workload. With this in mind, none of the participating legislators feel that their own salaries are too high; however, a fair number of Conservative legislators think of their salary as being "just right." A strong majority (79.3 percent) feel that their salary is too low. Considering party affiliation, ideology and district composition, the trend for those content with the compensation is clear: Conservative Republicans from rural districts are satisfied with current levels of compensation while Democrats, both liberal and moderate, would like to see an increase in Legislator salary. Associated with salary is the amount of resources given to each legislator to hire staff and supply their offices.

\section{Ideology vs Staffing Levels}

Previous calculations of legislature staffing levels have focused only on the total staff employee by the legislature and then divides that by number of legislators in a given state. This all-encompassing number includes both the partisan staff employed by legislative offices as well as non-partisan committee, fiscal and budget, and legal staff. Legislators utilize non-partisan staff for writing bills and parsing the fiscal and budgetary outcomes of legislation, yet have little direct control over their management. In parsing the effect partisanship has on the professionalization process, I therefore was largely uninterested in nonpartisan staff and was more directly concerned with how legislators staffed their own offices. When looking at the level 
of partisan staff each member employs annually a slight differentiation between urban liberal Democrats and rural conservative Republicans in Oregon emerges.

[Table Five about here]

According to the survey data, (see table five), Democrats are slightly more inclined hire individual part time staff while Republicans are more likely to share their staff between offices. Regardless of party affiliation most every member of the Oregon legislature hires one full-time partisan staff member. The major split between the parties is over part-time staff vs. shared staff. A near unanimous majority of Democrats admitted to hiring at least one part-time staff member, presumably for when they legislature is in session and workloads are increased. Just over fifty percent of republicans also hire part-time staff, yet four out of nine also conceded to sharing staff between other member offices. Based on the data, is does appear the Democrats are slightly more inclined to staff their offices at slightly higher levels. Another explanation could be that Republicans employ a smaller pool of people than Democrats and share them between their offices. Effectively this would make a "shared" staff member full time in terms of the number of hours work per week. These "shared" full time staffers would then split their work between offices as needed. Such a phenomena is not absent from Democratic members. The data merely suggests it is much more common among Republicans. Another way to look at the Table 5 data is to assign numerical values for each type of staff member employed annually.

To make the comparison of Table 5 more clear the following formula was devised to calculate in numerical terms the number of annual partisan staff employed by each member:

$(($ Full Time Staff $* 1)+($ Part Time Staff *.5) + (Shared Staff*.25)) / Number of Respondents 
Full time staff work year round, so a value of 1 was the obvious choice. In Oregon, part time staff are often either 6 month hires for the legislative session or work only part time ${ }^{55}$ throughout the year, therefore a value of .5 was applied. Finally, shared staff are only valued at .25 because their workload is spread around between various member offices. Even if shared staff ultimately work full time, each member who shares in their employment only utilizes their support for a limited duration, and likely not throughout the entire year. The results of these calculations are shown on Table Six.

[Table Six about here]

This data more clearly supports the assertion that Democrats staff their offices as slightly higher levels than do their Republican counterparts. Moreover, liberals and those in urban areas are also more likely to have incrementally larger staff than conservatives or members from rural districts. Considering not only staffing levels but also session length and legislative salary, the survey data gathered from Oregon legislators strongly indicates a relationship between partisanship and levels of professionalization. Having established tentative connections between partisanship and three main factors which contribute to the Squire Index. However, political party and ideology proved not to be explanatory factors when it comes to legislator preferences surrounding the issue of employee staff over the long term vs. hiring new staff every few years.

\section{$\underline{\text { Section Three: Data Analysis }}$}

A tentative relationship has been established between ideology and the main three ingredients of the Squire Index. I now turn back to Squire to see if the implications of this study can shed any light on explaining the outliers created by Squire's measurement. If ideology has a measurable impact on formation on legislator salary, session length, and staffing Squire's index

\footnotetext{
${ }^{55}$ Less than 30 hours per week
} 
should reflect that with historically conservative, republican dominated states receiving lower scores than their historically liberal, democratic counterparts. Additionally Fiorina was not wrong to assert that such a relationship exists, he was just mistaken to assume that the effects professionalization would have exponential impact on partisanship over time.

\section{Ideology and Squire}

State GDP remains be the most consistent indicator of professionalization, however, the preliminary results of this study indicate large variations between states with similar GDPs may, in fact, be the result of the partisan differences between those states. Squire is strongly of the opinion of the opinion that State Wealth is the best explanatory factory in explaining State Professionalism. The data collected through my research has not disproven that theory. My assertion is that the GDP model is largely incomplete without accounting for the ideological preferences. Figure four displays the data from Figure one. ${ }^{56}$ The data was then color coded ${ }^{57}$ with blue representing states that have been controlled by Democrats and red for states controlled by Republicans. ${ }^{58}$

[Figure four about here]

Republican states, like their Democratic counterparts, do exhibit an uptick in professionalization score as GDP increases but only to a certain point. Consistently Republican states Florida and Texas rank substantially lower on the Squire Index than one would think considering their size of their GDP. Distinguishing features of both Texas and Florida is that they both hold shorter sessions than more professional legislatures. In 2003, annual legislator salary in

\footnotetext{
56 See Page 14

${ }^{57}$ State party alignment was determined by examining party control of state legislators from 1992-2010. States were considered to be blue or red when the Democrats or Republicans held both house of the legislature for $60 \%$ of that time period. States not falling into either category were left out of consideration. Those states are as follows: Alaska, Kentucky, Indiana, Virginia, Nevada, Michigan, and Wisconsin.

58 “State Party Control." NCLS Website. <http://www.ncsl.org/research/about-state-legislatures/legislative-session-length.aspxv>. Accessed $5 / 04 / 2014$
} 
Florida was $\$ 27,000$ annually and in Texas it was only $\$ 7,200$. Compare this to New York where in 2003 legislators were compensated with $\$ 79,000$ annually and there are no limits on session length. Republican states were moderately supportive of some aspects of professionalization; the data indicates that politics plays some role in determining to what extent reforms are adopted. Republicans may support some measures of Professionalization, but only to a certain point. One major weakness of figure one is that it fails to take into account ideological differences between the States. Democrats in the south are known to be much more conservative than their northern or western counterparts. The same analysis used with figure four can be conducted using party ideology rankings ${ }^{59}$ for each state.

[Figure five about here]

Looking at the Squire Index in terms of ideology provides an even clearer picture of the general influence ideology may have on state politics. Within political parties regional ideological variations are commonplace. While Democrats historically have held majorities in several southern states they are also remarkably more conservative. Recent elections ${ }^{60}$ have seen democrats lose their majorities in states such as Arkansas, Mississippi and Alabama. While party control has changed frequently in some states, the median ideology of the two parties is much more static. Recently Boris Shor and Nolan McCarty mapped the ideology of state legislatures ${ }^{61}$ States with a majority of legislatures leaning conservative can be grouped together and compared to the states where a majority of legislators lean liberal. Using the Shor/McCarty data $^{62}$ I grouped the states on figure 5 into three categories based on their ideological score: Liberal (blue), conservative (red), and Moderate (black). California's data was used in

\footnotetext{
${ }^{59}$ Shor, Borris; McCarty, Nolan. "The Ideological Mapping of American Legislatures.” American Politican science Review (August 2011), 105:3, pp 530-551.

${ }^{60}$ Particularly 2010 and 2012.

${ }^{61}$ Shore (2011).

${ }^{62}$ Ibid
} 
calculating the trend line but the data point is not pictured. Looking at figure five, the trend lies indicate that states where liberals control the legislature have a propensity to score higher on the Squire Index than conservative controlled ones with similar GDPs. The relative wealth of a state remains a major factor behind professionalization; however, the main components of the Squire Index are not the direct result of GDP. The level of staff support, length of legislative session, and legislator salaries are all policy decisions made at some point or another by a given legislature. A high GDP in New York may have contributed to the legislature decided to pass reforms to increase session length or staff resources, but ultimately it was the policy choice of New York to pass such reforms. Conversely it is the policy choice of less professional, conservative states such as Texas or Florida, to not to institute such changes, or at least to pass more modest versions of reform. Having demonstrated how the Squire Index may be understood better through the lens of ideology, the 1994 Fiorina article should be re-examined.

\section{Implications of Ideologv:}

Fiorina's article pointed out that while individual events in professionalization may have created positive outcomes from Democrats, those trends produced little to no gain over time. Fiorina quite astutely pointed out that following the move in the State of Ohio toward annual sessions democrats were able to pick up large seat gains in an otherwise strong Republican election year of 1972. It would be illogical to assume, however, that this effect would last more than a single election or two. The effect of annual sessions was not so powerful such that it would cause a continuous gain of Democratic seats. At a certain point, the effect would plateau. Despite theoretical reservations about time commitment and the increases in session length, enough Republicans would still serve in the legislature. Certainly the professionalization of Congress has not kept ideologically conservative members from holding office, despite their 
potential objections to an increase in the size of government. The case of Oregon has illustrated ideology can play a role in several key areas of professionalism.

The survey data from Oregon demonstrates a measurable ideological impact on the propensity of a given legislator to support expanded session length as well as increased staffing levels. Urban liberals, on average, staff their offices at an incrementally higher rate than their rural conservative counterparts. Moreover, liberals universally support reforms expanding legislative session length while conservative remain split on the issue. Applying these concepts to other states might help explain differences in professionalization levels among states with similar populations and economies. The effects of partisanship can also be used to explain past changes in professionalization as well. Some scholars ${ }^{63}$ have pointed to the influx of urban liberals following the Supreme Court Cases of Barker v. Carr and Reynolds v. Sims as the foundation of the professionalization movement.

The effects of Baker v. Carr and Reynolds v. Sims had inherently partisan consequences. Both of these cases dealt with the issue of how states were to design their legislative district, and have been referenced by many scholars as the beginning of the professionalization movement at the state level. Prior to this, many senators and representatives were elected by county, without regard to the fact that some urban counties were vastly more populous than rural ones. Rural citizens, therefore, had far greater representation in state legislatures than did those living in cities. Reynolds v. Sims established what is known colloquially as the "one person, one vote" precedent, meaning that no individual should be more represented in the legislature than any other individual. This ushered in a large contingent of new legislators from urban areas, which is

\footnotetext{
${ }^{63}$ Pound, William. "State Legislative Careers, Twenty-Five Years of Reform," in Changing Patterns in State Legislative Careers, ed. Gary Moncrief et al. (University of Michigan Press, 1992). pp 9-22.
} 
to say liberal democrats were huge beneficiaries of this change. This has led some scholars ${ }^{64}$ to these court cases as the birth of legislative professionalism. If it can be said that legislative professionalism was born out of ideology, then it illogical to assume that ideology does not hold some weight in influencing relative levels of professionalization in various states.

\section{Study Limitations and Future Directions}

Case studies will always have the problem of not being more broadly applicable, despite the similarities between the subject and other related cases. I will continue to defend the assertion Oregon makes a solid case worth studying. The aforementioned work of Yin, (1984), also lends validity to this study. The recent switch to annual sessions is something most states had accomplished, at least some extent, thirty years prior. Moving forward further survey data should be gathered comparing the ideological preferences of state legislators with the choices they make when it comes to staffing, salary increases, and other reforms in professionalization. As ideology varies within political parties across the country, the political party affiliation should not be expected to be very predictive of professionalization levels. Ideology, at least in the case of Oregon, proved to be extremely effective in explaining the switch to annual sessions.

However, before any major conclusions may be drawn outside of Oregon, further research is needed examining this trend.

One possible line of inquiry could take the form of a comparative study between states with similar GDP yet fairly different professionalization scores. The previously mentioned split between a generally conservative Texas and the more liberal New York would be a great place to start. If the Oregon data is predictive of anything, one could easily conclude that New York

\footnotetext{
${ }^{64}$ See Pound (1992) also Karl Kurtz (1974) "Legislative Organization and Services" in Book of the States (1974-1975). <http://knowledgecenter.csg.org/kc/system/files/bos_1974_2.pdf> Accessed May 31, 2014
} 
professionalized due to a generally broader ideological acceptance of an enlarged role for government. Texas, on the other hand, resisted reforms as a reflection of the more conservative legislator's beliefs in limiting the size of government and support for the private sector. A split would also be expected along rural/urban lines, with those members from rural areas of Texas and New York being generally more opposed to a state legislature that more resembles congress.

\section{Conclusion:}

As legislatures continue evolve, it is important to continuously test previous conclusions and experiment with explanations, such as ideology, as possible factors that may contribute to those evolutions. The ever changing state legislatures should be viewed as laboratories in which consistent and rigorous experiments can be conducted. The Squire Index is only one measure by which legislatures can be compared on the macro level. The data gathered in this study demonstrates that individual reforms can be highly influenced by ideological preferences. While scholars have debated the various measurements and causes of professionalization legislators have also taken notice of these changes. Legislators should not be looked at as somehow separate from the equation of professionalization. Rather they are active participants in both its advancement in as well as in other cases the barrier to its development. Their views, which are inherently partisan, shape the ways state government function and can have a noticeable impact on the extent to which a given legislature may professionalize. 


\section{$\underline{\text { Tables }}$}

\section{Table One:}

Sample of State rankings from Squire Index

\begin{tabular}{|l|l|}
\hline State & Squire Index (2003) \\
\hline California & .626 \\
\hline Michigan & .342 \\
\hline Texas & .199 \\
\hline Oregon & .159 \\
\hline New Hampshire & .027 \\
\hline
\end{tabular}

\begin{tabular}{|c|c|c|c|}
\hline Table Two & Liberal & Moderate & Conservative \\
\hline \multirow{3}{*}{$\begin{array}{l}\text { Democrats: } \\
\text { Republicans: }\end{array}$} & 10 & 8 & 0 \\
\hline & 0 & 1 & 8 \\
\hline & Urban & Mix & Rural \\
\hline \multirow{2}{*}{$\begin{array}{l}\text { Democrats: } \\
\text { Republicans: }\end{array}$} & 12 & 6 & 1 \\
\hline & 0 & 2 & 7 \\
\hline
\end{tabular}

${ }^{65}$ Peverill Squire. State Legislatures Today: Politics Under the Domes. Ed. Gary Moncreif. Pearson Education, Inc. (2010): p 87. 


\begin{tabular}{|c|c|c|c|}
\hline Table Three & $\begin{array}{l}\text { The change to ann } \\
\text { Unnecessary }\end{array}$ & $\begin{array}{l}\text { ual sessions was: } \\
\text { Necessary }\end{array}$ & Still not Long Enough \\
\hline \multirow{3}{*}{$\begin{array}{l}\text { Democrats } \\
\text { Republicans }\end{array}$} & 1 & 15 & 3 \\
\hline & 5 & 4 & 0 \\
\hline & Unnecessary & Necessary & Still not Long Enough \\
\hline \multirow{4}{*}{$\begin{array}{l}\text { Liberal } \\
\text { Moderate } \\
\text { Conservative }\end{array}$} & 0 & 7 & 3 \\
\hline & 1 & 6 & 0 \\
\hline & 5 & 3 & 0 \\
\hline & Unnecessary & Necessary & Still not Long Enough \\
\hline \multirow{3}{*}{$\begin{array}{l}\text { Urban } \\
\text { Mix } \\
\text { Rural }\end{array}$} & 1 & 8 & 2 \\
\hline & 0 & 6 & 1 \\
\hline & 5 & 2 & 0 \\
\hline
\end{tabular}

\begin{tabular}{|c|c|c|c|c|}
\hline Table Four & Legislator Salary & n Oregon is: & & \\
\hline & Too Low & Just Right & Too High & \\
\hline Democrats & 20 & 0 & & 0 \\
\hline Republicans & 3 & 6 & & 0 \\
\hline & Too Low & Just Right & Too High & \\
\hline Liberal & 10 & 0 & & 0 \\
\hline Moderate & 9 & 0 & & 0 \\
\hline Conservative & 3 & 6 & & 0 \\
\hline & Too Low & Just Right & Too High & \\
\hline Urban & 12 & 0 & & 0 \\
\hline Mix & 9 & 0 & & 0 \\
\hline Rural & 2 & 6 & & 0 \\
\hline
\end{tabular}




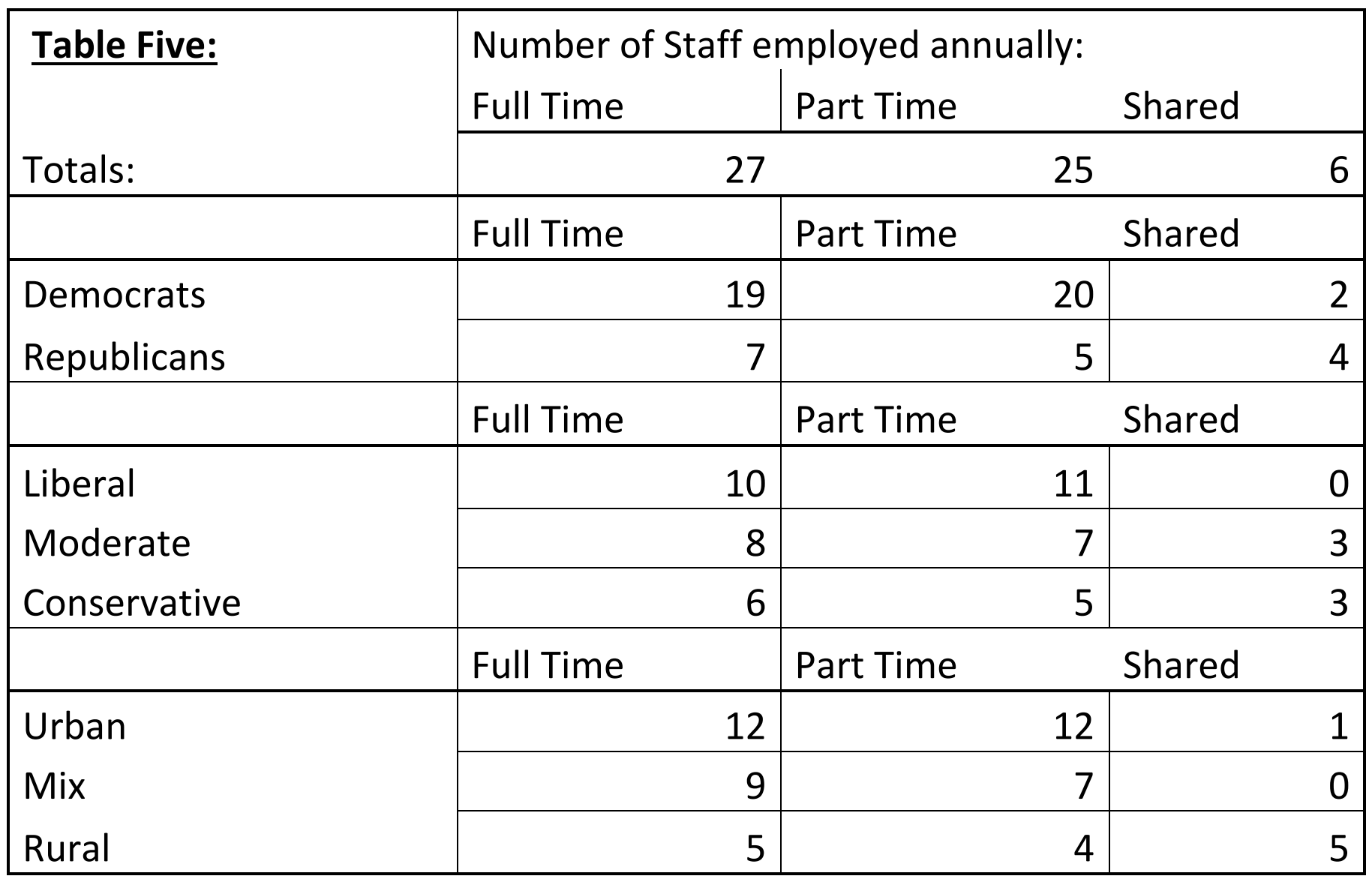

\begin{tabular}{|l|r|}
\hline Table Six: & Annual Staff Per Legislator \\
\hline Democrats & 1.48 \\
\hline Republicans & 1.17 \\
\cline { 2 - 3 } & \\
\hline Liberal & 1.55 \\
\cline { 2 - 3 } Moderate & 1.36 \\
\hline & 1.16 \\
\hline Urbanservative & 1.52 \\
\hline Mix & 1.39 \\
\cline { 2 - 2 } Rural & 1.03 \\
\hline
\end{tabular}




\section{Figures}
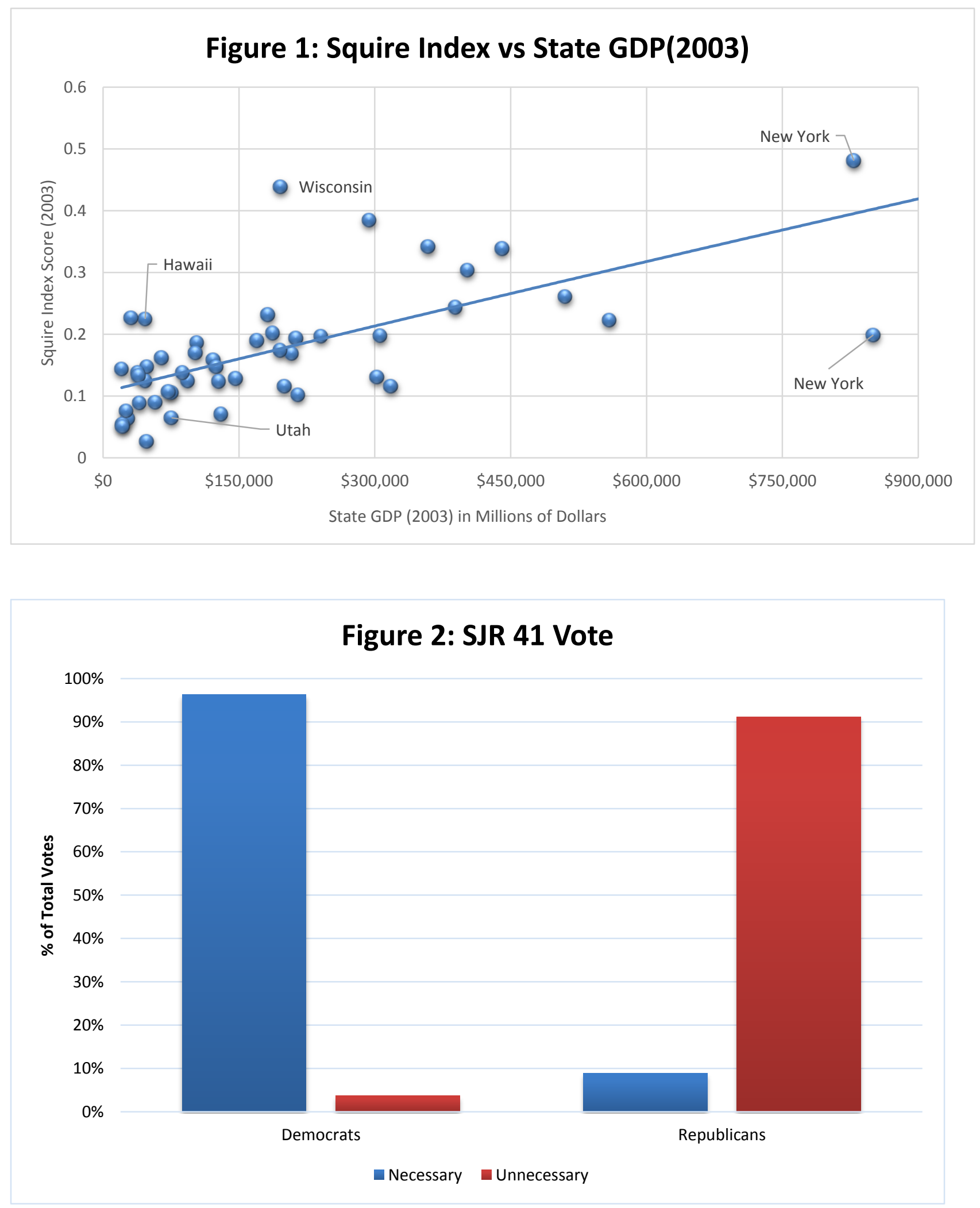


\section{Figure 3: Anual Sessiosn by Party}
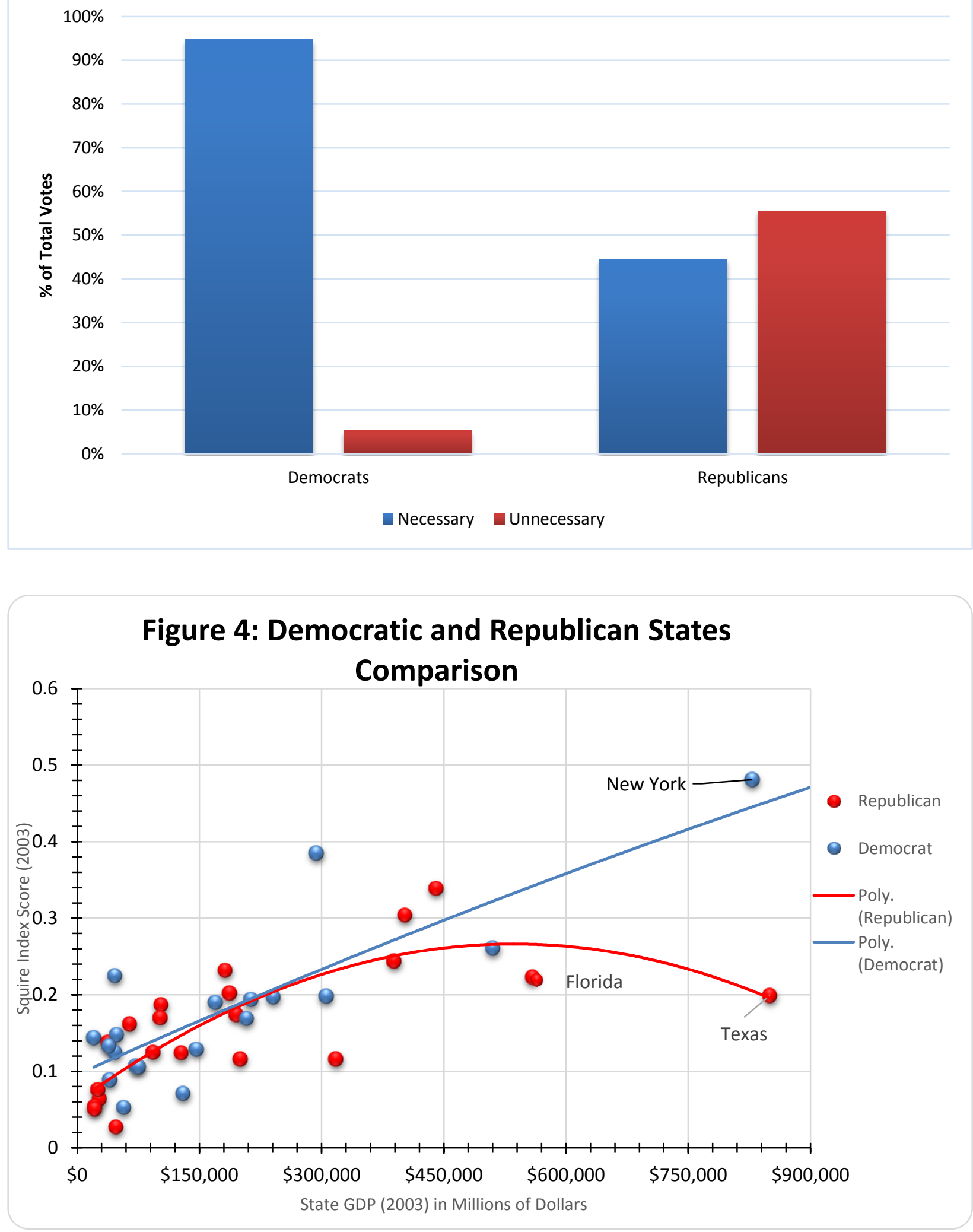
Figure 5: Ideology: Squire Index vs GDP

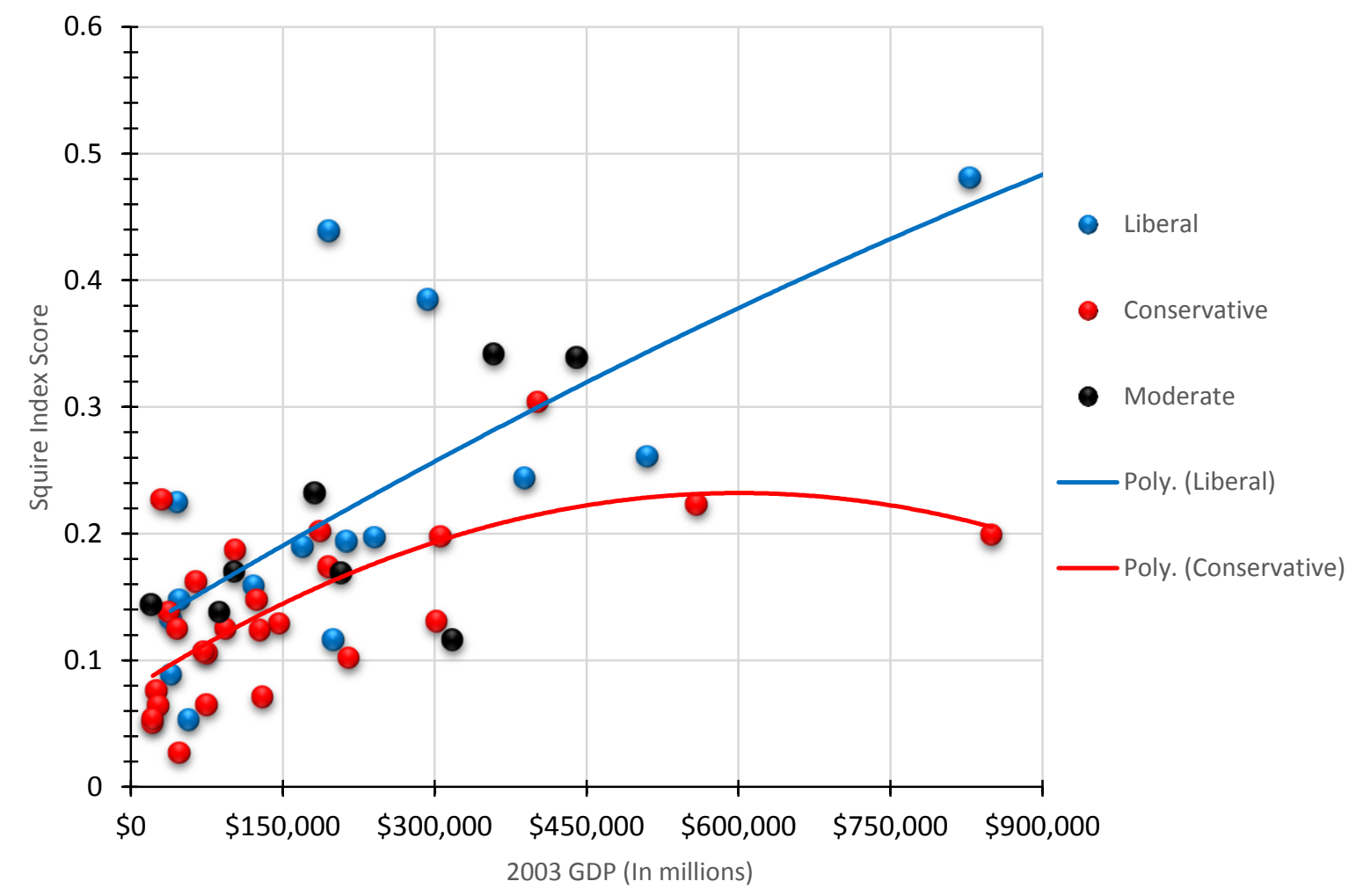




\section{Appendix A}

\begin{tabular}{|c|c|}
\hline Criteria & Recommendations \\
\hline Functional & $\begin{array}{l}\text { Remove restrictions on session length, frequency, and agenda. } \\
\text { Provide more staff to leadership, committees, and members. } \\
\text { Provide adequate office facilities for leadership, staff, commit- } \\
\text { tees, and members. } \\
\text { Use deadlines and rules to regulate flow of legislation. } \\
\text { Reduce the number of committees and individual committee } \\
\text { assignments. }\end{array}$ \\
\hline Accountable & $\begin{array}{l}\text { Use single-member districts to elect members. } \\
\text { Election of legislative leaders by full membership or party } \\
\text { caucus. } \\
\text { Increase public access to legislative actions and decisions. } \\
\text { Provide greater access to the press and news media. }\end{array}$ \\
\hline Informed & $\begin{array}{l}\text { Use pre- and interim session periods to draft and consider } \\
\text { legislation. } \\
\text { Increase the number and kinds of legislative staff and ser- } \\
\text { vices. } \\
\text { Reduce the number of standing committees. } \\
\text { Upgrade bill-drafting capability. }\end{array}$ \\
\hline Independent & $\begin{array}{l}\text { Remove restrictions on session length, frequency, and agenda. } \\
\text { Provide legislative control over its budget and salaries. } \\
\text { Increase the legislature's budget authority and role. } \\
\text { Increase legislative oversight capability. } \\
\text { Regulate lobbyists. } \\
\text { Adopt conflict of interest provisions. }\end{array}$ \\
\hline Representative & $\begin{array}{l}\text { Use single-member districts to elect members. } \\
\text { Provide resources for district offices. } \\
\text { Keep restrictions on holding office to a minimum. } \\
\text { Provide adequate compensation to members. } \\
\text { Diffuse legislative leadership and authority. } \\
\text { Guarantee minority membership office and staff resources } \\
\text { and committee assignments. }\end{array}$ \\
\hline \multicolumn{2}{|c|}{$\begin{array}{l}\text { SOURCE: Compiled from Citizens Conference on State Legislatures, State } \\
\text { Legislatures: An Evaluation of Their Effectiveness (New York: Praeger Publishers, } \\
\text { 1971). }\end{array}$} \\
\hline
\end{tabular}




\section{Appendix B}

\begin{tabular}{|c|c|c|c|c|c|}
\hline Red & Red Light & Wl & nite & Blue Light & Blue \\
\hline $\begin{array}{l}\text { California } \\
\text { Michigan } \\
\text { New York } \\
\text { Pennsylvania }\end{array}$ & $\begin{array}{l}\text { Illinois } \\
\text { Florida } \\
\text { Ohio } \\
\text { Massachusetts } \\
\text { New Jersey } \\
\text { Wisconsin }\end{array}$ & $\begin{array}{l}\text { Alabama } \\
\text { Alaska } \\
\text { Arizona } \\
\text { Arkansas } \\
\text { Colorado } \\
\text { Connecticut } \\
\text { Delaware } \\
\text { Hawaii } \\
\text { lowa } \\
\text { Kentucky } \\
\text { Louisiana } \\
\text { Maryland } \\
\text { Minnesota }\end{array}$ & $\begin{array}{l}\text { Missouri } \\
\text { Nebraska } \\
\text { North } \\
\text { Carolina } \\
\text { Oklahoma } \\
\text { Oregon } \\
\text { South } \\
\text { Carolina } \\
\text { Tennessee } \\
\text { Texas } \\
\text { Virginia } \\
\text { Washington }\end{array}$ & $\begin{array}{l}\text { Georgia } \\
\text { Idaho } \\
\text { Indiana } \\
\text { Kansas } \\
\text { Maine } \\
\text { Mississippi } \\
\text { Nevada } \\
\text { New } \\
\text { Mexico } \\
\text { Rhode } \\
\text { Island } \\
\text { Vermont } \\
\text { West } \\
\text { Virginia }\end{array}$ & $\begin{array}{l}\text { Montana } \\
\text { New } \\
\text { Hampshire } \\
\text { North } \\
\text { Dakota } \\
\text { South } \\
\text { Dakota } \\
\text { Utah } \\
\text { Wyoming }\end{array}$ \\
\hline
\end{tabular}

Red: Professional Legislatures; White Semi-Professional Legislatures ; Blue: Citizen Based Legislatures

\section{Time on Job, Average Pay, and Average Staff by category of Legislature}

\begin{tabular}{|l|l|l|l|}
\hline Category of Legislature & $\begin{array}{c}\text { Time on the Job } \\
\text { (1) }\end{array}$ & $\begin{array}{c}\text { Compensation } \\
(\mathbf{2})\end{array}$ & $\begin{array}{c}\text { Staff per } \\
\text { Member (3) }\end{array}$ \\
\hline Red & $80 \%$ & $\$ 68,599$ & 8.9 \\
\hline White & $70 \%$ & $\$ 35,326$ & 3.1 \\
\hline Blue & $54 \%$ & $\$ 15,984$ & 1.2 \\
\hline
\end{tabular}

\section{Notes:}

1. Estimated proportion of a full-time job spent on legislative work including time in session, constituent service, interim committee work, and election campaigns.

2. Estimated average annual compensation of legislators including salary, per diem, and any other unvouchered expense payments.

3. Ratio of total legislative staff to number of legislators. This includes central legislative staff offices, so it is not a measure of how many staff work directly for each legislator. 


\section{Appendix C}

Thank you for choosing to participate in this survey. By participating, you agree to have your answers complied and published in the form of survey data. Individual answers will not be published or made public.

\section{Background Information:}

In the 1950s state legislatures looked amateurish in comparison to Congress - legislators on the state level were understaffed, underpaid, and only were in session a few months per year. Political Scientist Alexander Heard described the state legislature of the mid-twentieth century as institutionally "poorly organized; technically ill-equipped; functioning with inadequate time, staff, and space; and operating with outmoded procedures and committee systems" ${ }^{\prime 66}$ However, over the past fifty years, a reform movement to transform state legislatures into a more Congress-like body occurred. Scholars have labeled this movement the process of "professionalization."

Legislative professionalism can be generally defined as the movement of State Legislatures to the same level of organizational support as Congress. This means "providing State Legislatures with adequate resources to do their jobs in a manner comparable to Congress" Adequate resources include, but are not limited to, "expanded legislative sessions, superior staff resources, and sufficient pay to allow members to peruse legislative service as their vocation."

\section{Professionalization in Oregon:}

The history of the professionalization of Oregon's legislature is similar to that of many other states. Oregon's most major effort to modernize its legislature was in 1967, when the legislature "created an advisory committee to study and recommend reforms." In 1968, the committee's report was issued and the state legislature chose to adopt some, but not all of the recommended reforms. Following national trends, initial reforms included "increased legislators' pay, removed constitutional restrictions on session lengths, and hired more staff." The expanded session length and additional staff was meant to increase institutional professionalism by giving legislators the professional support they needed to do their jobs. The increase in salary worked to make the position of "legislator" more financially viable as permanent vocation. Further reforms came in the late 1970's and early 1980's, when a 12.5 million dollar renovation of the Oregon Capitol building "added further space for legislative offices, hearing rooms, support services, a first floor galleria, and underground parking." ${ }^{67}$ Additionally resources were made available for full time staff to assist legislators in their duties. This phenomenon in Oregon did not stop with the changes of the 60 's, 70's and 80 's. It remains an ongoing process in all fifty states today.

\section{Purpose of this Survey:}

The main function is to ascertain how legislators and their staff perceive the changes that have taken place in the Oregon State Legislature over the past 50 years. As legislatures continue to modernize their institutions and behavior, it continues to be important to research and track these changes.

\footnotetext{
${ }^{66}$ Alan Rosenthal, Engines of Democracy: Politics \& Policymaking in State Legislatures, (Washington, DC: CQ Press, 2009), 183-184

${ }^{67}$ Oregon Legislature Website. http://www.leg.state.or.us/capinfo/legislative_history.pdf
} 


\section{Appendix D}

\section{$\underline{\text { Survey }}$}

1. What is your party affiliation?
a) Democratic
b) Republican
c) Other
d) Prefer not to say

2. Ideologically, do you generally consider yourself to be:
a) Libertarian
b) Conservative
c) Liberal
d) Socialist/Social Democrat
e) Moderate
f) Prefer not to say

3) I consider my primary occupation to be: (Please Check One)

\begin{tabular}{|l|l|l|l|}
\hline & Full-Time Legislator & Communications \\
\hline Attorney & & Medical Professional \\
\hline Business: Owner & & Music/Arts \\
\hline & Business: Executive/Manager & Government Employee: Local \\
\hline & Agriculture & Government Employee: State \\
\hline & Retired & Homemaker \\
\hline & Educator: K-12 & Engineer/Scientist/Architect \\
\hline Educator: College & & Clergy \\
\hline & Consultant/Professional/Non-Profit & & Labor Union \\
\hline & Real Estate & & Insurance \\
\hline
\end{tabular}

4) How many years have you held public office? (As a legislator)
a) Under 2 years
b) 2-5 years
c) 5-10 years
d) 10-15 years
e) $15+$ years

5) In thinking about the district you represent, do you consider it to be: 

a) Mostly Urban
b) Mostly Rural
c) A mix of Rural and Urban

6) Salaries (including per-diem pay) of State Legislators in Oregon are
a) Too High
b) Just right
c) Too low

7) If your financial compensation as a legislator were to be adequately comparable with the compensation of your occupation outside the legislature, would you consider being a legislator as a full time occupation? (ie, would you leave your job outside the legislature to focus on your responsibilities within the legislature).
a) Yes
b) No
c) Being a legislator is already my full time vocation / I am retired outside the legislature

8) While IN session, my duties as a State Legislator require week.
a) $0-10$
b) $10-20$
c) $20-30$
d) $30-40$
e) $40+$

9) While NOT in session, my duties as a State Legislator requires hours of my time per week. (This includes Leg Days, Constituent Work, and any other duties related to the legislature)
a) $0-10$
b) $10-20$
c) $20-30$
d) $30-40$
e) $40+$

10) The move to annual legislative sessions, (one long session, one short session), in Oregon was
a) A necessary change
b) An unnecessary change
c) Indifferent
D) Didn't go far enough, full sessions should be held annually

11) How many staff does your office employ annually? (Please provide a number, your office staff does not include committee staff)

_ Full Time (Year Round) _ _ _ Part Time (Session)

Shared Staff (Between your and other legislator's offices)

12) If additional resources were to be allocated for staffing in the capitol, I would advocate that they be directed toward salary increases and/or additional staffing for: (Circle all that apply)
a) Legislator Office Staff (Partisan)
b) Caucus Staff (Partisan) 
c) Committee Staff (Non-Partisan) d) Legislative Council / Fiscal Revenue Staff

e) Legislator Salaries f) Staffing levels are currently adequate

\section{3) If additional resources were allocated for legislative offices I would:}
a) Increase Staffing levels (hire more staff)
b) Increase current staff salaries
c) Invest in new office equipment/supplies
d) A combination of $\mathrm{A}, \mathrm{B}$, and $\mathrm{C}$

e) My office is adequately staffed and supplied.

\section{4) Given the option I would prefer my office staff:}

a) Remain in my employment as long as possible. More experienced staff helps my office run more effectively.

b) Remain in my employment over several sessions, but new staff can easily be hired and trained

c) Remain mostly part time, temporary positions. I rely mostly on committee, legislative council, fiscal and revenue, and/or caucus staff for the majority of my support as a legislator.

Thank you for choosing to participate in this survey. Again, your answers will be kept anonymous. The results of my research will be published this summer and available online. It is my hope that it will provide useful insight into the "state of the legislature," and my findings will serve to highlight ways in which the legislature can better serve the citizens of the State of Oregon. 


\section{Bibliography}

Citizens Conference on state Legislatures. 1971, State legislatures: An Evaluation of Their Effectiveness. New York: Praeger.

Clucas, Richard A. “The Legislature," In Oregon Politics and Government: Progressives versus Conservative Populists, edited by Richard A. Clucas, Mark Henkels, and Brent S. Steel, 115-133. Omaha: University of Nebraska Press, 2005.

Farmer, Rick; Riddle, Thomas. "Legislative Leadership" Institutional Change in American Politics: The Case of Term Limits, edited by Karl T. Kurtz, Bruce Cain, and Richard G. Niemi, 55-72. Ann Arbor: University of Michigan Press, 2007.

Freeman, James. “Congress, Go Home and Stay Home," USA Today, 11 August 1999, editorial

Fiorina, Morris P. "Divide Government in the American States: A Pyproduct of Legislative Professionalism?" American Political Science Review. 88.2: 304-16

Grumm, John G. 1971. "The Effects of Legislative Structure on Legislative Performance." In State and Urban Politics, eds. Richard I Hofferbert and Ira Sharkansky. Boston, MA: Little, Brown.

Hamm, Keith; Squire, Peverill. 101 Chambers: Congress, State Legislatures, and the Future of Legislative Studies. Ohio State University Press, 2005.

Hedge, David M. Governance and the Changing American States. Boulder: Westview Press, 1998

Kousser, Thad. Term Limits and the Dismantling of State Legislative Professionalism, (New York: Cambridge University Press, 2005), 91. 
Kurtz, Karl T. "Understanding the Diversity of American State Legislatures." Legislative Studies Quarterly. 25: 327-43.

Kurtz, Karl T., Gary Moncrief, Richard G. Niemi, and Lynda W. Powell. "Time, Term Limits, and Turnover: membership Stability in U.S. State Legislatures." Legislative Studies Quarterly 29: 357-81

Kurtz, Karl. T, Gary Moncrief, Richard G. Niemi, and Lynda W. Power. 2006. 'Full-Time, PartTime, and Real Time: Explaining State Legislators' Perceptions of Time on the Job.” State Politics and Policy Quarterly 6:322-38.

Malhotra, Neil. "Disentangling the Relationship between Legislative Professionalism and Government Spending,” Legislative Studies Quarterly 33(2008): 287-414

Moncrief, Gary F. Joel A. Thompson, Michael Haddon, and Robert Hoyer. "For whom the Bell Tolls: Term Limits and State Legislatures." Legislative Studies Quarterly 17: 37-47

National Conference of State Legislatures. 2004. "Size of State Legislative Staff: 1979, 1988, 1996, and 2003."http://www.ncsl.org/programs/legman/about/staffcount 2003.htm.” (November 10, 2013).

National Conference of State Legislatures. 2008. "Full-and Part-Time Legislatures." http://www.ncsl.org/research/about-state-legislatures/full-and-part-timelegislatures.aspx.” (March 14, 2014).

Owings, Stephanie, and Rainald Borck. "Legislative Professionalism and Government Spending: Do Citizen Legislators Really Spend Less?" Publish Finance Review 28: $210-25$

Pound, William. "State Legislative Careers, Twenty-Five Years of Reform," in Changing Patterns in State Legislative Careers, ed. Gary Moncrief et al. (University of Michigan Press, 1992). pp 9-22. 
Rosenthal, Alan. "The Legislative Institution: Transformed and at Risk," In The State of the States, edited by Carl E. Van Horn. Washington, DC: CQ Press, 1981

Rosenthal, Alan. 1993. "The Legislative Institution: In Transition and at Risk." In The State of the States, ed. Carl E. Van Horn. 2nd ed. Washington, DC: CQ Press.

Rosenthal, Alan. 1996. "State Legislative Development: Observations from Three Perspectives." Legislative Studies Quarterly. 21:169-98.

Rosenthal, Alan. Engines of Democracy: Politics \& Policymaking in State Legislatures, Washington, DC: CQPress, 2009.

Shor, Borris; McCarty, Nolan. "The Ideological Mapping of American Legislatures.” American Politican science Review (August 2011), 105:3, pp 530-551.

Squire, Peverill. The Evolution of American Legislatures, (Ann Arbor, University of Michigan Press, 2009)

Squire, Peverill. "Measuring State Legislative Professionalism: The Squire Index Revisted," State Politics and Policy Quarterly, 7(2007): 211-227

Squire, Peverill. Institutional Change in American Politics: The Case of Term Limits, (Ann Arbor: University of Michigan Press, 2007)

Peverill Squire. State Legislatures Today: Politics Under the Domes. Ed. Gary Moncreif. (Pearson Education, Inc,2010): p 87.

Woods, Neal D; Baranowski, Michael. "Legislative Professionalism and Influence on State Agencies: The Effects of Resources and Careerism," Legislative Studies Quarterly, 31(2006): 585-609.

Yin, Robert. "The Case Study Crisis: Some Answers.” Administrative Science Quarterly, Vol. 26, No. 1 (Mar.,1981), pp. 58-65 
